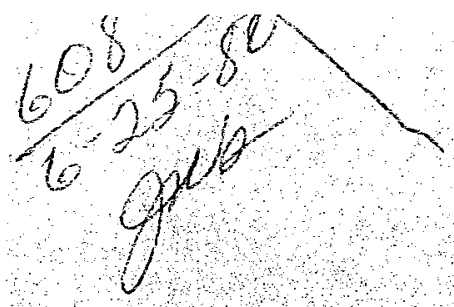

44.1389

LBL 10080

to

UC-66b

\title{
PACKER INJEGTION TEST DATA FROM SITES ON FRACTURED ROCK
}

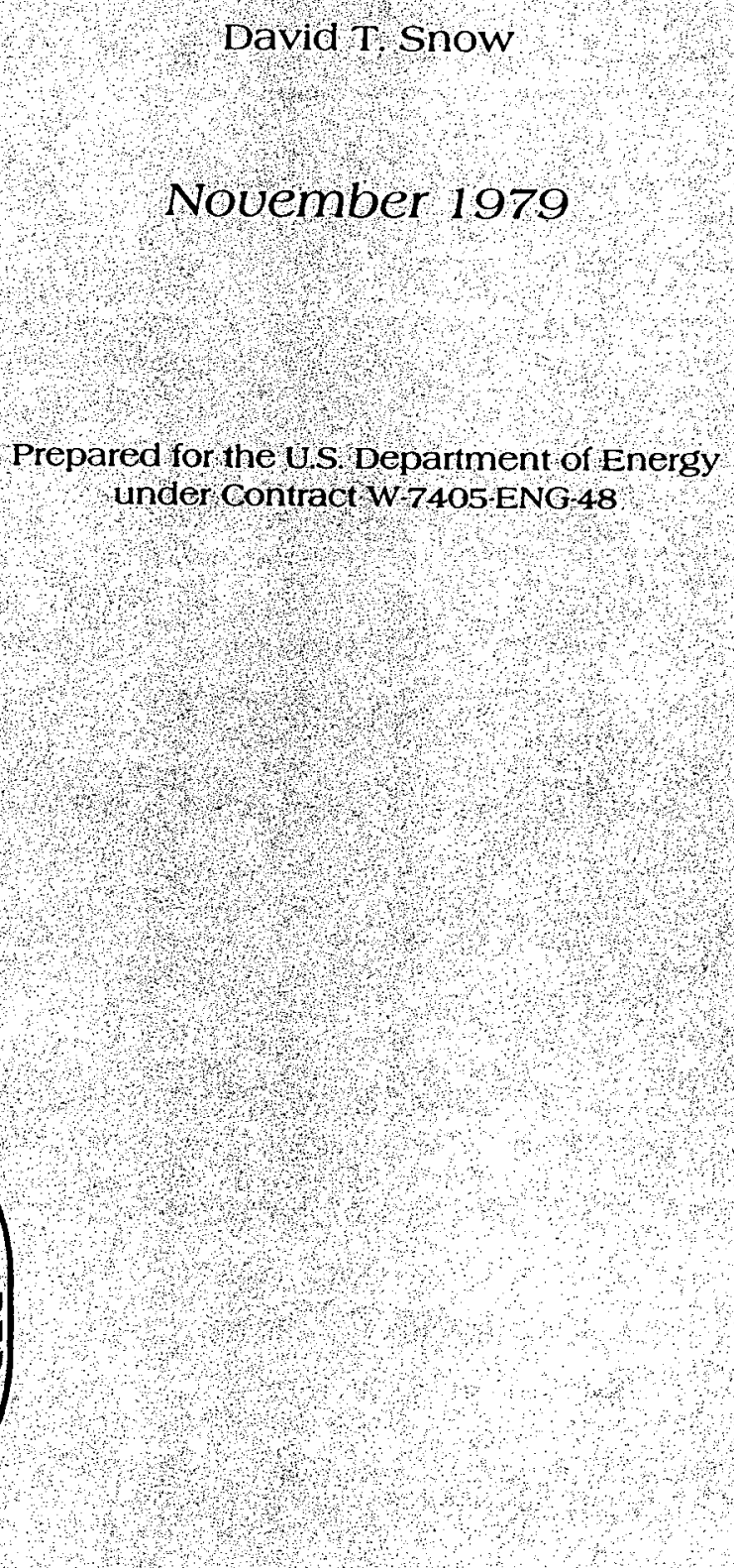




\section{LEGAL NOTICE}

This book was prepared as an account of work sponsored by an agency of the United States Government Neither the United States Govern ment nor any agency thereof, nor any of their employees, makes any warranty, express or im plied, orassumés any legal liability or responsibility for the accuracy, completeness, or usefulness of any information, apparafus, product, or process disclosed, or represents that its use would not infringe privately, owned tights Reference herein to any specific commercial product, process, or service by trade name, trademark, manufacturer, or otherwise, does not necessarily constitute or imply its endorsement, recommendation or favoring by the United States Government on any agency thereof The views and opinions of authors ex pressed herein do not hecessarily state or reflect those of the United States Govennment or any agency thereof:

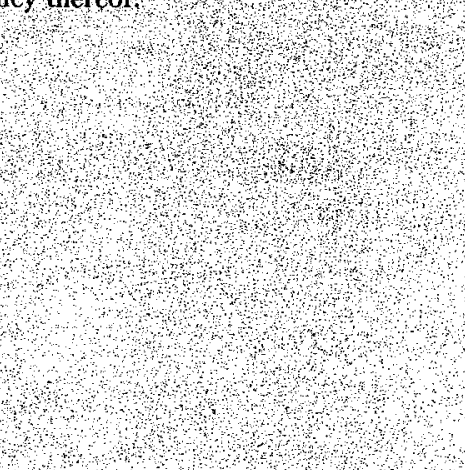

Printed in the United States of America Available from

National Technical Information Service

US Department of Commerce

5285 Port Royal Road

Springfield, VA 22161

Price Code A02 


\section{DISCLAIMER}

This report was prepared as an account of work sponsored by an agency of the United States Government. Neither the United States Government nor any agency Thereof, nor any of their employees, makes any warranty, express or implied, or assumes any legal liability or responsibility for the accuracy, completeness, or usefulness of any information, apparatus, product, or process disclosed, or represents that its use would not infringe privately owned rights. Reference herein to any specific commercial product, process, or service by trade name, trademark, manufacturer, or otherwise does not necessarily constitute or imply its endorsement, recommendation, or favoring by the United States Government or any agency thereof. The views and opinions of authors expressed herein do not necessarily state or reflect those of the United States Government or any agency thereof. 


\section{DISCLAIMER}

Portions of this document may be illegible in electronic image products. Images are produced from the best available original document. 
PACKER INJECTION TEST DATA FROM SITES ON FRACTURED ROCK

\author{
David T. Snow \\ Groundwater and Geological Engineering \\ Colorado Springs, Colorado 80907
}

\title{
November 1979
}

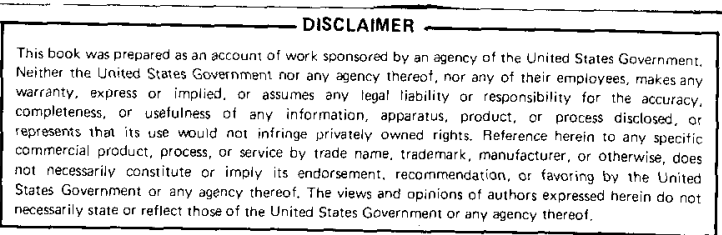

States Government or any agency thereof. The views and opinions of authors expressed herein do not
necessarily state or reflect those of the United States Government or any agency thereof. 


\begin{abstract}
Packer tests conducted in drill holes in fractured rocks at dam and tunnel sites are the primary data for characterizing permeabilities, fracture spacings, apertures and porosities. A collection of data, numbering 5862 tests at 41 sites between the surface and $200 \mathrm{~m}$ depth in 12 different fractured crystalline rock types is reported on microfiche. In addition to the discharge and collar pressure, each entry records the angle and size of drill hole, the inclined depths to the top and bottom of the test interval, the depth to the static water level and the bottom of overburden. A summary of computed permeabilities, porosities, fracture spacings and apertures, averaged for several depth zones at each site are tabulated, and publications derived from the data are referenced.
\end{abstract}


PACKER INJECTION TEST DATA FROM SITES ON FRACTURED ROCK

Fractured rock is a permeable medium which may store and transmit groundwater and dissolved constituents. Its characterization is currently of interest to several areas of geotechnical engineering, such as radioactive waste storage, geothermal energy recovery, and in situ methods of mining, to mention a few. Permeability data for fractured rocks are valuable because of the high cost of drilling in such rocks as granite, metamorphics, or cemented sediments. Also, permeability data are useful for predictive and correlative purposes, and for generic or site-specific studies. The object of this paper is preservation of 5862 water injection tests from 41 sites, largely in western U. S. A. Logs of borings containing the records of the majority of the water-injection tests were furnished by the Denver and Sacramento offices of the U. S. Bureau of Reclamation. Others were provided by Woodward-C1yde-Sherard and Assoc., Oakland; Soils Mechanics and Foundations Engineers, Inc., Palo Alto, California; and by J. L. Turk, Lynn Brown, and Barry McMahon. Jerry Hiatt and the writer interpreted the logs and keypunched the data. American Cyanamid Co. provided financial support for that effort.

The data for the 5682 water injection tests are included in this report as microfiche copy in a pocket inside the back cover.

Tests were selected from borings at a site to represent a reasonably homogeneous rock type in each data-set, e.g., granite was separated from gneiss, diabase from gabbro, etc. With the exception of sites personally known to the writer, no field inspection nor study of reports or literature were made for 
discriminatory purposes. In most cases the original logs as well as supporting maps and reports may be obtained at offices of the contributing agencies. In some cases there are fracture data on record such as orientations, spacings, fillings, etc.; in other cases field study would be required, but these would be hampered by the fact that outcrops are covered in the course of construction and landscaping.

Thirty-three of the data sets represent damsites and eight, tunnels. In each the tests were conducted in vertical or inclined (downward only) drill holes of small diameter. The data have been extracted from the logs of grout holes and exploration drill holes, most of which followed the form described in the Earth Manual (U. S. Bur. of Reclamation, 1963, p. 161). Water tests are recorded in terms of discharge and pressure together with necessary information such as the position of the static water level, the rock type, fracturing and the depth of overburden, the hole size and inclination, and the packer locations. For each test presented as a line of record in this report (microfiche enclosed), the following items are labeled:

1. ANGLE, the inclination of the drill hole (degrees) from the horizontal. Most are vertical, i.e., 90.0;

2. TOP, the inclined depth (feet) to the top of the test section, the upper of two packers set to isolate the length of hole tested;

3. Bоттом, the inclined depth (feet) to the bottom of the test section, which may be the lower of two packers in some cases, or the bottom of the open hole in others.

For permeability computation, the length of hole between packers through which 
water discharges to the formation, is BOTTOM-TOP. In some procedures packers at fixed spacing are moved as a pair, both measures changing by the same amount between tests. In other procedures, a single packer is moved a regular inclined distance relative to the bottom of the hole. Provided that pressures are applied uniformly among tests in a hole, the incremental discharge through an interval of hole bounded by successive upper packer positions is the difference between discharges for those two tests. Since hole numbers have not been recorded, the identity of the hole must be established by noting progres-

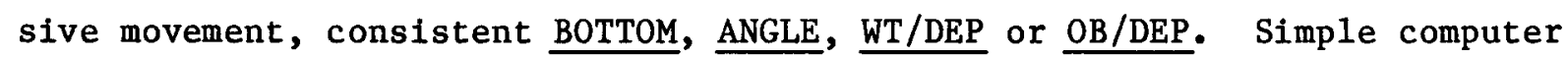
programs have been written for such data handling. In few cases are damsite exploration holes deeper than $600 \mathrm{ft}$, and economy usually limits tunnel explorations to similar depths. Thus the data relate primarily to shallow bedrock, largely $300 \mathrm{ft}$ or less, below surface. A cut-off of testing at depth is in part because permeability tends to diminish rapidly with depth. Consequently, it is believed that rock fracture openings have been induced by destressing during erosional and excavational unloading.

4. WT/DEP, the inclined depth (feet) to the water table, as observed (at some time) in the hole.

In ideal logging procedures, the observation is made days after the drilling has been completed or at the start of water testing, so that a reasonable approach to equilibrium is made. It is believed that most of the data were collected in a conscientious manner; about $80 \%$ of them were done in accordance with instructions in the Earth Manual, Test Designation E-18, which resulted in good uniformity and reliability even though obtained by numerous different 
observers during a span of 10-15 years at a variety of project sites. No indications of variations of quality have been recorded though numerous logs were rejected for that reason.

5. DISCH, the discharge (gallons per minute) is the flow rate recorded at the surface during injection testing, presumed to be the rate of $\mathrm{flow}$ between packers into the formation.

Rates have generally not been determined precisely because low flow rates are less significant for dam foundation engineering than are high flow rates. Prediction of foundation water leakage is a prime objective as is delineation of foundation areas requiring remedial grouting. Usually, a diaphragm-type integrating water meter is used at the beginning and end of a 5-10 minute pseudosteady pumping period. In cases of extreme discharge, rates are measured with an orifice or venturi-type meter and in rare cases of vanishing rate, by measuring the fall of levels in a water-supply vessel such as a 55-gallon drum. Because drill holes are seldom located or oriented at random, but rather are planned to intercept prominent weaknesses or water conduits such as faults, the data contain an inevitable bias towards the higher values. Because measurement devices are insensitive below $1 \mathrm{gpm}$, fractional discharges are not always determined accurately; a nominal zero or $1 \mathrm{gpm}$ is sometimes recorded. With the crude devices often employed, the practical minimum aperture of a fracture that will register measureable flow is about 35 microns. Furthermore, there is seldom assurance that packer leakage has been eliminated, so fractional discharges may sometimes represent null flow into the formation. No information on packer type or pressure has been noted. The actual conditions 
of unsteady, constant-pressure testing are not preserved on logs or in the data. The conventional basis of assumed steady-state packer injection testing and analysis has been summarized by Snow (1966).

Tests are generally prolonged sufficiently to be asymptotic to a steady state unless very low permeability prevails. Thus some uncertainty of permeability must remain for discharges below $1 \mathrm{gpm}$. Analysis of pressure-test discharges, especially after normalization to some standard conditions, has demonstrated that as a statistic, discharge or permeability is highly skewed towards the sma11 values. This attribute, along with the observed frequency of zero discharges, has been used to estimate in situ fracture spacing and thereby average apertures and porosities consistent with the permeabilities (Snow, 1968a).

In these interpretations it has been assumed that resistive granular filling materials are absent and that velocities are so low that roughness does not grossly invalidate the assumption of a parallel-plate analogue in computation of an equivalent aperture. Assuming that a lognormal distribution appropriately represents fracture apertures at depth as well as the outcrop (Bianchi and Snow, 1969), it is possible to compute two parameters that describe lognormal distributions of fracture apertures from each given set of injection test data (Snow, 1969b). Discharge measures are rarely distorted by turbulent losses in fractures. Using the criterion of Baker (1955), with the critical Reynolds number

$$
\mathrm{R}=\mathrm{Q} / \pi \mathrm{r} \nu=6000 ; \quad \mathrm{Q} / \mathrm{r}=247 \mathrm{~cm}^{2} / \mathrm{sec},
$$

5532 of the tests were examined (Snow, 1969a). Since the precise number of 
fractures contributing to each test is unknown, the discharge per fracture was estimated by dividing the discharge per test by the average number of fractures per test interval. On that basis, slightly over $3 \%$ of the tests attained turbulence beyond the wall radius, $r$. Discharge would have to exceed $15 \mathrm{gpm}$ from an NX borehole. Most turbulence dies out within two or three radii for typical packer tests in fractured rock. However, it is evident that packer tests evaluate fracture properties only close to the hole - Baker (1955) found that in laminar flow $80 \%$ of the head is dissipated within a foot of the hole, even for a $1 \mathrm{~mm}$ aperture. Clearly the characteristics of most fractures, being finer, are tested to a distance of at most a rew radii.

6. PRESS is the pressure (pounds per square inch) recorded at the surface during testing.

In no case has cavity pressure been recorded. Mundi and Wallace (1973) have described the equipment, techniques, and methods of interpretation commonly employed in packer-testing fractured rock foundations. The typical field equipment for pressure measurement is a Bourdon gauge, a mercury manometer, or in some cases, air pressure over a reservoir tank maintained by a regulator. Precision is usually to the nearest half psi with collar pressures of 25, 50, or sometimes $100 \mathrm{psi}$. The net pressure at the test section can be computed according to the difference in elevation of the (static) water table and the collar of the hole, less the estimated head losses in the typical drill-string and fittings, at the measured discharge. Rissler (1978) has examined the various components of head loss, including entrance losses at a single fracture. In all cases involving tests in a section at successively higher pressures, the 
lowest pressure test has been recorded because of the wel1-known nonlinearity displayed by fractures subject to progressive opening with increased pressure. Discharge can more readily be standardized to a common pressure, say 25 psi net, if al1 measures are taken at low net pressures. Examples of standardization are given in Snow $(1965,1968 \mathrm{a}, 1969 \mathrm{~b})$. Many test sections become permeable only at high pressures, in response to fracture parting. These distorted measures have been avoided to the fullest degree possible.

7. SIZE is the drill hold diameter (inches). Most are NX holes of 3-inch nominal diameter.

8. $\mathrm{OB} / \mathrm{DEP}$ is the inclined depth (feet) to the bottom of any overburden materials disclosed in the 1 og.

These include younger formations covering the bedrock such as alluvium, blown sand, or bedded sediments overlying an unconformity. Whereas the existing total stresses in a rock mass would be related more closely to the total depth below ground surface, taking density variations into account, the fracture apertures and therefore permeabilities are believed associated with the minimum depth during the geologic history of a site. The vertical depth below the base of overburden may be computed as a parameter against which such measures as fracture permeability are compared. In few cases do the data relate directly to total or effective stress since the subsurface test locations have not been related to the topography and water table configuration. Valley sites may be subject to V-notch stress concentrations and convergent, effluent groundwater flow patterns, currently of unknown character at each site. 
Reports generated from these data are listed in the references, treating such parameters as permeability, porosity, spacings, and fracture aperture distributions. Table 1 lists average properties for depth zones at each site (with few exceptions), reported graphically elsewhere (Bianchi and Snow, 1969; Snow, 1968a, 1968b, 1969b). Because the exploration sites on hard crystalline fractured rocks represent some 12 different rock types, the data may be applicable to the estimation of conditions at many prospective sites and to the pursuit of new interpretation techniques. 


\section{REFERENCES}

Baker, W. J., 1955. Flow in fissured formations. Proc. 4th World Petrol Congress, Rome, Sect. II/E, paper 7, pp. 379-393.

Bianchi, L. and D. T. Snow, 1969. Permeability of crystalline rock interpreted from measured orientations and apertures of fractures. Annals of Arid Zone, Jodhpur, India, vol. 8, no. 2, pp. 231-245.

Bureau of Reclamation, 1963. Earth Manual, 1st ed., revised, 783 pp.

Mundi, E. K. and J. R. Wa1lace, 1973. On the permeability of some fractured crystalline rocks. Bull. Assoc. Eng. Geol., vol. 10, no. 4, pp. 299-312.

Rissler, P., 1978. Determination of the water permeability of jointed rock. Inst. for Found. Eng., Soll Mech., Rock Mech. and Waterways Construction, Aachen, vol. 5 (English ed.), 150 pp.

Snow, D. T. and R. H. Karol, 1965. Estimation of fracture porosity in crystalline rock. Chemical Grouting Topics No. 5, Amer. Cyanamid Co., Wayne, N. J., 9 pp. 2 figs.

Snow, D. T., 1966. Three-hole pressure-test for anisotropic foundation permeability. Felsmechanik und Ingenieurgeologie, vol. IV, no. 4, pp. 288-315.

Snow, D. T., 1968a. Rock fracture spacings, openings and porosities. Jour. Soil Mech. and Found. Div., ASCE, vol. 94, no. 1, pp. 73-91.

Snow, D. T., 1968b. Hydraulic character of fractured metamorphic rocks of the Front Range and implications to the Rocky Mt. Arsenal We1l. Quart. Colo. School of Mines, vol. 63, no. 1, pp. 167-199.

Snow, D. T., 1969a. Closure to discussions, rock fracture spacings, openings and porosities. Jour. Soil Mech. \& Found. Div., ASCE, vol. 95, no. 3, pp. 880-883.

Snow, D. T., 1969b. The frequency and apertures of fractures in rock. Int' 1 Jour. Rock Mech. \& Mining Sci., vol. 6, no. 4, pp. 23-40. 
Table 1. Summary of computed average properties of fractured rocks.

\begin{tabular}{|c|c|c|c|c|c|}
\hline Location & $\begin{array}{l}\text { lid-depth below } \\
\text { verburden ( } f t)\end{array}$ & $\begin{array}{l}\text { permeability } \\
\left(f t^{2}\right)\end{array}$ & porosity & $\begin{array}{l}\text { aperture } \\
\text { (microns) }\end{array}$ & $\begin{array}{c}\text { spacing, cubic } \\
\text { system }(f t)\end{array}$ \\
\hline $\begin{array}{l}\text { Spring Creek } \\
\text { Tunnel, Calif. } \\
\text { granite }\end{array}$ & $\begin{array}{l}42 . \\
43 . \\
111 . \\
113 . \\
273 . \\
266 .\end{array}$ & $\begin{array}{l}1.58 \times 10^{-12} \\
3.51 \\
1.40 \\
.53 \\
.09 \\
.53\end{array}$ & $\begin{array}{l}1.33 \times 10^{-4} \\
1.99 \\
1.21 \\
.74 \\
.12 \\
.52\end{array}$ & $\begin{array}{c}111 . \\
108 . \\
93 . \\
82 . \\
35 . \\
89 .\end{array}$ & $\begin{array}{r}8.2 \\
5.3 \\
7.5 \\
10.7 \\
29.6 \\
16.9\end{array}$ \\
\hline $\begin{array}{l}\text { Auburn Damsite } \\
\text { No. 1, Calif. } \\
\text { granite }\end{array}$ & $\begin{array}{l}34 \\
83 \\
146\end{array}$ & $\begin{array}{l}1.63 \times 10^{-12} \\
.64 \\
.32\end{array}$ & $\begin{array}{l}1.23 \times 10^{-4} \\
.48 \\
.35\end{array}$ & $\begin{array}{c}102 \\
72 \\
58\end{array}$ & $\begin{array}{r}8.2 \\
14.5 \\
16.4\end{array}$ \\
\hline $\begin{array}{l}\text { Folsom Damsite } \\
\text { Calif. } \\
\text { granite }\end{array}$ & $\begin{array}{l}27 \\
42 . \\
52 . \\
68\end{array}$ & $\begin{array}{l}3.67 \times 10^{-12} \\
1.57 \\
.86 \\
3.30\end{array}$ & $\begin{array}{l}1.85 \times 10^{-4} \\
1.29 \\
.60 \\
1.25\end{array}$ & $\begin{array}{r}114 . \\
85 \\
97 \\
100\end{array}$ & $\begin{array}{r}6.1 \\
6.5 \\
15.9 \\
7.8\end{array}$ \\
\hline $\begin{array}{l}\text { T-2 Power Cavern } \\
\text { Australia, } \\
\text { granite }\end{array}$ & $\begin{array}{l}23 . \\
49 . \\
70 \\
90 \\
110 \\
136 \\
180 \\
246 \\
331 \\
550\end{array}$ & $\begin{array}{l}4.00 \times 10^{-10} \\
5.80 \times 10^{-12} \\
2.91 \\
1.85 \\
3.24 \\
8.78 \times 10^{-10} \\
5.94 \times 10^{-12} \\
.022 \\
.85 \times 10^{-14} \\
1.02\end{array}$ & $\begin{array}{l}3.95 \times 10^{-4} \\
2.57 \\
1.32 \\
1.16 \\
.60 \\
1.19 \\
.43 \\
.089 \\
.017 \\
.048\end{array}$ & $\begin{array}{r}277 . \\
138 . \\
114 \\
94 \\
113 . \\
474 \\
112 . \\
30 \\
18 \\
24\end{array}$ & $\begin{array}{r}6.9 \\
5.3 \\
8.5 \\
8.0 \\
18.6 \\
39.3 \\
25.4 \\
33.2 \\
107.5 \\
48.5\end{array}$ \\
\hline $\begin{array}{l}\text { Wells Hydro Proj. } \\
\text { Washington, } \\
\text { granite }\end{array}$ & $\begin{array}{l}8 . \\
21\end{array}$ & $\begin{array}{l}4.50 \times 10^{-12} \\
78.3\end{array}$ & $\begin{array}{l}1.09 \times 10^{-4} \\
.41\end{array}$ & $\begin{array}{r}88 . \\
183 .\end{array}$ & $\begin{array}{r}7.9 \\
44.0\end{array}$ \\
\hline $\begin{array}{l}\text { Two Forks Damsite } \\
\text { Colorado, } \\
\text { gneiss }\end{array}$ & $\begin{array}{l}19 . \\
82 .\end{array}$ & $\begin{array}{l}3.91 \times 10^{-12} \\
5.00 \times 10^{-15}\end{array}$ & $\begin{array}{l}.18 \times 10^{-4} \\
.54 \times 10^{-6}\end{array}$ & $\begin{array}{l}78 \\
10\end{array}$ & $\begin{array}{r}41.5 \\
189.8\end{array}$ \\
\hline $\begin{array}{l}\text { Upper Crystal Dam- } \\
\text { site, Colorado, } \\
\text { gneiss }\end{array}$ & $\begin{array}{l}10 \\
40 \\
77 \\
152\end{array}$ & $\begin{array}{l}3.24 \times 10^{-12} \\
2.39 \\
.91 \\
.81\end{array}$ & $\begin{array}{l}2.32 \times 10^{-4} \\
.86 \\
.51 \\
.63\end{array}$ & $\begin{array}{l}127 \\
121 \\
82 \\
74\end{array}$ & $\begin{array}{r}5.4 \\
13.8 \\
15.9 \\
11.5\end{array}$ \\
\hline
\end{tabular}


Table 1. Summary of computed average properties of fractured rocks (continued).

\begin{tabular}{|c|c|c|c|c|c|}
\hline Location & $\begin{array}{l}\text { Mid-depth below } \\
\text { overburden ( } t t \text { ) }\end{array}$ & $\begin{array}{l}\text { permeability } \\
\left(f t^{2}\right)\end{array}$ & porosity & $\begin{array}{l}\text { aperture } \\
\text { (microns) }\end{array}$ & $\begin{array}{c}\text { spacing, cubic } \\
\text { system ( } f t)\end{array}$ \\
\hline $\begin{array}{l}\text { Morrow Point } \\
\text { Damsite, Colo. } \\
\text { gneiss }\end{array}$ & $\begin{array}{l}9 . \\
17 . \\
27 . \\
39 . \\
50 . \\
61 . \\
72 . \\
83 . \\
94 . \\
114 . \\
138 . \\
182 .\end{array}$ & $\begin{array}{l}5.58 \times 10^{-12} \\
8.12 \\
14.9 \\
6.25 \\
3.45 \\
4.48 \\
1.83 \\
2.19 \\
2.42 \\
.83 \\
.44 \\
.51\end{array}$ & $\begin{array}{l}1.51 \times 10^{-4} \\
2.40 \\
4.06 \\
2.32 \\
1.10 \\
1.55 \\
.84 \\
.70 \\
.77 \\
.40 \\
.17 \\
.40\end{array}$ & $\begin{array}{l}160 . \\
164 . \\
193 . \\
159 . \\
131 . \\
137 . \\
104 . \\
113 . \\
109 . \\
78 . \\
52 . \\
68 .\end{array}$ & $\begin{array}{r}10.4 \\
6.7 \\
4.7 \\
6.7 \\
11.7 \\
8.7 \\
12.3 \\
15.8 \\
13.9 \\
19.1 \\
30.8 \\
16.7\end{array}$ \\
\hline $\begin{array}{l}\text { Blue Mesa Damsite, } \\
\text { Colorado, } \\
\text { gneiss }\end{array}$ & $\begin{array}{l}6.5 \\
15 . \\
25 . \\
35 . \\
51 . \\
69 . \\
90 . \\
121 . \\
191 . \\
298 .\end{array}$ & $\begin{array}{l}1.87 \times 10^{-10} \\
.10 \\
1.83 \times 10^{-12} \\
1.29 \\
.44 \\
.48 \\
.27 \\
.27 \\
.14 \\
8.36 \times 10^{-14}\end{array}$ & $\begin{array}{l}3.01 \times 10^{-4} \\
1.91 \\
.76 \\
.41 \\
.12 \\
.20 \\
.26 \\
.23 \\
.15 \\
.21\end{array}$ & $\begin{array}{c}231 . \\
148 . \\
108 . \\
94 . \\
54 . \\
57 . \\
53 . \\
52 . \\
39 . \\
38 .\end{array}$ & $\begin{array}{r}7.5 \\
7.6 \\
13.9 \\
22.4 \\
44.0 \\
28.2 \\
20.2 \\
21.9 \\
26.0 \\
17.8\end{array}$ \\
\hline $\begin{array}{l}\text { Tooma-Tumut Dam, } \\
\text { Australia, } \\
\text { gneiss }\end{array}$ & $\begin{array}{l}45 . \\
85 \\
120 \\
209\end{array}$ & $\begin{array}{l}2.52 \times 10^{-12} \\
.82 \\
.33 \\
3.32 \times 10^{-14}\end{array}$ & $\begin{array}{l}1.25 \times 10^{-4} \\
.73 \\
.21 \\
.14\end{array}$ & $\begin{array}{l}136 \\
91 \\
70 \\
36\end{array}$ & $\begin{array}{l}10.7 \\
12.3 \\
33.1 \\
25.2\end{array}$ \\
\hline $\begin{array}{l}\text { Latrobe Damsite, } \\
\text { California, } \\
\text { meta-argilite }\end{array}$ & 47. & $2.67 \times 10^{-12}$ & $.45 \times 10^{-4}$ & 110 & 24.1 \\
\hline $\begin{array}{l}\text { Snelling Damsite, } \\
\text { California, } \\
\text { slate }\end{array}$ & $\begin{array}{l}21 . \\
38 .\end{array}$ & $\begin{array}{l}3.50 \times 10^{-12} \\
3.13\end{array}$ & $\begin{array}{l}1.97 \times 10^{-4} \\
2.16\end{array}$ & $\begin{array}{l}139 . \\
116 .\end{array}$ & $\begin{array}{l}6.9 \\
5.2\end{array}$ \\
\hline $\begin{array}{l}\text { Exchequer Spill- } \\
\text { way, California, } \\
\text { slate, talc schist }\end{array}$ & $\begin{array}{l}17 . \\
36 .\end{array}$ & $\begin{array}{l}4.82 \times 10^{-12} \\
3.31\end{array}$ & $\begin{array}{l}2.43 \times 10^{-4} \\
2.76\end{array}$ & $\begin{array}{l}135 . \\
114\end{array}$ & $\begin{array}{l}5.5 \\
4.1\end{array}$ \\
\hline $\begin{array}{l}\text { Auld Valley Dam- } \\
\text { site, California, } \\
\text { phyllite }\end{array}$ & $\begin{array}{l}20 . \\
68 .\end{array}$ & $\begin{array}{l}4.88 \times 10^{-12} \\
.33\end{array}$ & $\begin{array}{l}.43 \times 10^{-4} \\
.77\end{array}$ & $\begin{array}{l}83 . \\
59 .\end{array}$ & $\begin{array}{r}19.2 \\
7.5\end{array}$ \\
\hline
\end{tabular}


Table 1. Summary of computed average properties of fractured rocks (continued).

\begin{tabular}{|c|c|c|c|c|c|}
\hline Location & $\begin{array}{l}\text { Mid-depth below } \\
\text { overburden ( } f t)\end{array}$ & $\begin{array}{l}\text { permeability } \\
\left(f t^{2}\right)\end{array}$ & porosity & $\begin{array}{l}\text { aperture } \\
\text { (microns) }\end{array}$ & $\begin{array}{c}\text { spacing, cubic } \\
\text { system ( } f t)\end{array}$ \\
\hline $\begin{array}{l}\text { Brown's Creek } \\
\text { Damsite, Calif. } \\
\text { mica schist }\end{array}$ & $\begin{array}{r}13 . \\
36 . \\
55 . \\
74 . \\
86 \\
103\end{array}$ & $\begin{array}{l}1.43 \times 10^{-9} \\
.66 \times 10^{-12} \\
.19 \\
.37 \\
.29 \\
.12\end{array}$ & $\begin{array}{l}1.23 \times 10^{-4} \\
.68 \\
.30 \\
.27 \\
.28 \\
.17\end{array}$ & $\begin{array}{l}400 . \\
71 . \\
52 . \\
58 . \\
51 . \\
39 .\end{array}$ & $\begin{array}{l}32.1 \\
10.2 \\
16.9 \\
20.8 \\
17.9 \\
22.2\end{array}$ \\
\hline $\begin{array}{l}\text { Slab Creek Dam- } \\
\text { site, Calif. } \\
\text { mica schist }\end{array}$ & $\begin{array}{l}18 . \\
57 .\end{array}$ & $\begin{array}{c}23.4 \times 10^{-12} \\
.38\end{array}$ & $\begin{array}{l}1.50 \times 10^{-4} \\
.16\end{array}$ & $\begin{array}{c}232 \\
74\end{array}$ & $\begin{array}{l}15.2 \\
44.3\end{array}$ \\
\hline $\begin{array}{l}\text { Chung-Ju Damsite, } \\
\text { Korea, } \\
\text { mica schist }\end{array}$ & $\begin{array}{r}12 \\
30 \\
52 \\
115\end{array}$ & $\begin{array}{l}2.06 \times 10^{-12} \\
1.98 \\
1.42 \\
.63\end{array}$ & $\begin{array}{l}.86 \times 10^{-4} \\
.55 \\
.50 \\
.56\end{array}$ & $\begin{array}{r}105 . \\
98 . \\
90 \\
60\end{array}$ & $\begin{array}{l}12.1 \\
17.5 \\
17.6 \\
10.5\end{array}$ \\
\hline $\begin{array}{l}\text { Papoose Damsite, } \\
\text { California } \\
\text { metavolcanics } \\
\text { (greenstone) }\end{array}$ & $\begin{array}{l}11 \\
35 \\
79\end{array}$ & $\begin{array}{l}9.80 \times 10^{-12} \\
3.57 \\
2.04\end{array}$ & $\begin{array}{l}1.74 \times 10^{-4} \\
1.15 \\
1.11\end{array}$ & $\begin{array}{r}123 \\
101 \\
83\end{array}$ & $\begin{array}{l}7.0 \\
8.7 \\
7.3\end{array}$ \\
\hline $\begin{array}{l}\text { Lewiston-Clear } \\
\text { Creek Tunnel, } \\
\text { California, } \\
\text { metarhyolite } \\
\text { (greenstone) }\end{array}$ & $\begin{array}{r}20 \\
66 \\
162\end{array}$ & $\begin{array}{l}45.0 \times 10^{-12} \\
1.08 \\
1.10\end{array}$ & $\begin{array}{l}2.25 \times 10^{-4} \\
.35 \\
.27\end{array}$ & $\begin{array}{l}200 \\
120 \\
108\end{array}$ & $\begin{array}{r}8.7 \\
33.7 \\
38.6\end{array}$ \\
\hline $\begin{array}{l}\text { Trinity Damsite, } \\
\text { California, } \\
\text { meta-andesite } \\
\text { (greenstone) }\end{array}$ & $\begin{array}{l}5 . \\
5 . \\
14 . \\
21 . \\
32 . \\
32 . \\
42 . \\
52 . \\
63 . \\
80 . \\
100 . \\
126 . \\
167 . \\
259 .\end{array}$ & $\begin{array}{l}1.18 \times 10^{-10} \\
1.86 \\
7.58 \times 10^{-12} \\
5.59 \\
27.6 \\
15.2 \\
2.24 \\
1.16 \\
.67 \\
2.62 \\
.79 \\
.76 \\
.033 \\
.00\end{array}$ & $\begin{array}{l}2.23 \times 10^{-4} \\
9.08 \\
1.34 \\
1.67 \\
3.33 \\
2.02 \\
1.67 \\
.72 \\
.40 \\
.50 \\
.54 \\
.43 \\
.047 \\
.00\end{array}$ & $\begin{array}{l}230 . \\
394 . \\
139 . \\
128 . \\
160 . \\
151 . \\
96 . \\
91 . \\
79 . \\
98 . \\
82 . \\
69 . \\
24 . \\
00 .\end{array}$ & $\begin{array}{r}10.1 \\
4.3 \\
10.3 \\
7.5 \\
4.7 \\
7.4 \\
5.6 \\
12.4 \\
19.6 \\
19.1 \\
15.1 \\
15.9 \\
50.7 \\
-\end{array}$ \\
\hline
\end{tabular}


Table 1. Summary of computed average properties of fractured rocks (continued).

\begin{tabular}{|c|c|c|c|c|c|}
\hline Location & $\begin{array}{l}\text {-depth below } \\
\text { rburden }(f t)\end{array}$ & $\begin{array}{l}\text { permeability } \\
\left(f t^{2}\right)\end{array}$ & porosity & $\begin{array}{l}\text { aperture } \\
\text { (microns) }\end{array}$ & $\begin{array}{l}\text { spacing, cubic } \\
\text { system ( } f t)\end{array}$ \\
\hline $\begin{array}{l}\text { Oroville Damsite, } \\
\text { California, } \\
\text { metavolcanic } \\
\text { amphibolite }\end{array}$ & $\begin{array}{l}122 . \\
142 . \\
252 . \\
282 . \\
383 . \\
395 .\end{array}$ & $\begin{array}{l}.67 \times 10^{-12} \\
.25 \\
.36 \\
.40 \\
.16 \\
.63\end{array}$ & $\begin{array}{l}.13 \times 10^{-4} \\
.084 \\
.22 \\
.20 \\
.046 \\
.22\end{array}$ & $\begin{array}{l}50 . \\
52 . \\
45 . \\
47 . \\
41 . \\
54 .\end{array}$ & $\begin{array}{l}39.7 \\
60.8 \\
20.0 \\
22.8 \\
86 . \\
24.2\end{array}$ \\
\hline $\begin{array}{l}\text { Mason Damsite, } \\
\text { Oregon, } \\
\text { meta-andesite }\end{array}$ & $\begin{array}{l}42 . \\
74 . \\
110 . \\
151 . \\
218 . \\
326 .\end{array}$ & $\begin{array}{l}8.35 \times 10^{-12} \\
.58 \\
.79 \\
.79 \\
.33 \\
.47\end{array}$ & $\begin{array}{l}2.24 \times 10^{-4} \\
.70 \\
.82 \\
.72 \\
.50 \\
1.12\end{array}$ & $\begin{array}{l}133 . \\
76 . \\
75 . \\
74 . \\
57 . \\
67 .\end{array}$ & $\begin{array}{r}5.8 \\
10.7 \\
9.0 \\
10.1 \\
11.2 \\
5.8\end{array}$ \\
\hline $\begin{array}{l}\text { Whiskeytown Dam- } \\
\text { site, Calif. } \\
\text { metarhyolite }\end{array}$ & $\begin{array}{r}10 . \\
29 \\
49 \\
81 \\
157\end{array}$ & $\begin{array}{l}26.0 \times 10^{-12} \\
1.82 \\
1.21 \\
5.05 \times 10^{-14} \\
\quad .00\end{array}$ & $\begin{array}{l}1.06 \times 10^{-4} \\
.35 \\
.21 \\
.025 \\
.00\end{array}$ & $\begin{array}{c}172 . \\
85 \\
66 \\
24 \\
00\end{array}$ & $\begin{array}{c}15.9 \\
23.8 \\
30.9 \\
92.9 \\
--\end{array}$ \\
\hline $\begin{array}{l}\text { Lewiston Damsite, } \\
\text { California, } \\
\text { metavolcanics } \\
\text { (greenstone) }\end{array}$ & $\begin{array}{l}7 . \\
30\end{array}$ & $\begin{array}{l}1.56 \times 10^{-9} \\
2.12 \times 10^{-12}\end{array}$ & $\begin{array}{l}3.09 \times 10^{-4} \\
.93\end{array}$ & $\begin{array}{l}476 \\
103\end{array}$ & $\begin{array}{l}15.1 \\
10.9\end{array}$ \\
\hline $\begin{array}{l}\text { Auburn Damsite } \\
\text { No. 2, Calif. } \\
\text { greenstone }\end{array}$ & $\begin{array}{l}15 . \\
53 . \\
92\end{array}$ & $\begin{array}{l}2.84 \times 10^{-10} \\
2.08 \times 10^{-12} \\
.52\end{array}$ & $\begin{array}{l}3.92 \times 10^{-4} \\
1.53 \\
.90\end{array}$ & $\begin{array}{c}382 \\
104 \\
71\end{array}$ & $\begin{array}{l}9.6 \\
6.6 \\
7.8\end{array}$ \\
\hline $\begin{array}{l}\text { Buffalo Rapids } \\
\text { Damsite, Wash., } \\
\text { quartzite-argillite }\end{array}$ & 56. & $3.22 \times 10^{-12}$ & $1.61 \times 10^{-4}$ & 117. & 7.2 \\
\hline $\begin{array}{l}\text { Geehi Damsite, } \\
\text { Australia, } \\
\text { blanket grout - } \\
\text { quartzite }\end{array}$ & $\begin{array}{l}11 \\
17 \\
22 \\
27\end{array}$ & $\begin{array}{l}6.90 \times 10^{-12} \\
7.24 \\
4.04 \\
2.23\end{array}$ & $\begin{array}{l}2.35 \times 10^{-4} \\
3.49 \\
1.31 \\
1.82\end{array}$ & $\begin{array}{l}154 \\
142 \\
154 \\
116\end{array}$ & $\begin{array}{r}6.4 \\
4.0 \\
11.6 \\
6.2\end{array}$ \\
\hline $\begin{array}{l}\text { Geehi Damsite, } \\
\text { Australia, } \\
\text { primary curtain - } \\
\text { quartzite }\end{array}$ & $\begin{array}{l}51 . \\
77 . \\
91 . \\
120 . \\
156 . \\
189 .\end{array}$ & $\begin{array}{l}1.18 \times 10^{-12} \\
.18 \\
.18 \\
.13 \\
5.10 \times 10^{-14} \\
2.88\end{array}$ & $\begin{array}{l}.74 \times 10^{-4} \\
.31 \\
.29 \\
.26 \\
.20 \\
.11\end{array}$ & $\begin{array}{r}105 . \\
65 \\
63 . \\
55 \\
44 \\
35\end{array}$ & $\begin{array}{l}13.9 \\
20.7 \\
21.8 \\
21.3 \\
21.2 \\
31.0\end{array}$ \\
\hline
\end{tabular}


Table 1. Summary of computed average properties of fractured rocks (continued).

\begin{tabular}{|c|c|c|c|c|c|}
\hline Location & $\begin{array}{l}\text {-depth below } \\
\text { rburden }(f t)\end{array}$ & $\begin{array}{l}\text { permeability } \\
\left(f t^{2}\right)\end{array}$ & porosity & $\begin{array}{l}\text { aperture } \\
\text { (microns) }\end{array}$ & $\begin{array}{c}\text { spacing, cubic } \\
\text { system ( } f t)\end{array}$ \\
\hline $\begin{array}{l}\text { Geehi Damsite, } \\
\text { Australia,, } \\
\text { secondary curtain } \\
\text { quartzite }\end{array}$ & $\begin{array}{l}47 . \\
70 \\
92 \\
140\end{array}$ & $\begin{array}{l}.34 \times 10^{-12} \\
.30 \\
.21 \\
6.27 \times 10^{-14}\end{array}$ & $\begin{array}{l}.47 \times 10^{-4} \\
.40 \\
.31 \\
.15\end{array}$ & $\begin{array}{l}74 . \\
67 . \\
62 . \\
44\end{array}$ & $\begin{array}{l}15.3 \\
16.7 \\
19.5 \\
28.7\end{array}$ \\
\hline $\begin{array}{l}\text { Geehi Damsite, } \\
\text { Australia, } \\
\text { tertiary curtain } \\
\text { quartzite }\end{array}$ & $\begin{array}{l}35 \\
49 \\
70 \\
115\end{array}$ & $\begin{array}{l}.92 \times 10^{-12} \\
.39 \\
.092 \\
.076\end{array}$ & $\begin{array}{l}.61 \times 10^{-4} \\
.38 \\
.088 \\
.31\end{array}$ & $\begin{array}{l}83 . \\
77 . \\
45 \\
49\end{array}$ & $\begin{array}{l}13.4 \\
20.2 \\
50.3 \\
15.7\end{array}$ \\
\hline $\begin{array}{l}\text { Paskenta Damsite, } \\
\text { California, } \\
\text { sandstone and shale }\end{array}$ & $\begin{array}{l}11 . \\
63 .\end{array}$ & $\begin{array}{l}16.4 \times 10^{-12} \\
2.10\end{array}$ & $\begin{array}{l}1.22 \times 10^{-4} \\
.44\end{array}$ & $\begin{array}{r}136 . \\
72 .\end{array}$ & $\begin{array}{l}10.9 \\
16.1\end{array}$ \\
\hline $\begin{array}{l}\text { Newville Reservoir, } \\
\text { California, } \\
\text { conglomerate and } \\
\text { sandstone }\end{array}$ & $\begin{array}{l}25 . \\
64 .\end{array}$ & $\begin{array}{l}1.91 \times 10^{-12} \\
.36\end{array}$ & $\begin{array}{l}1.04 \times 10^{-4} \\
.23\end{array}$ & $\begin{array}{r}110 . \\
80 .\end{array}$ & $\begin{array}{l}10.3 \\
33.8\end{array}$ \\
\hline $\begin{array}{l}\text { Newville Damsite, } \\
\text { California, } \\
\text { sandstone and } \\
\text { shale }\end{array}$ & $\begin{array}{l}18 \\
45 \\
77 \\
145\end{array}$ & $\begin{array}{l}16.8 \times 10^{-12} \\
1.50 \\
.94 \\
.26\end{array}$ & $\begin{array}{l}2.63 \times 10^{-4} \\
1.27 \\
.56 \\
.15\end{array}$ & $\begin{array}{r}187 . \\
98 . \\
86 . \\
47 .\end{array}$ & $\begin{array}{r}7.0 \\
7.6 \\
15.2 \\
29.9\end{array}$ \\
\hline $\begin{array}{l}\text { Pacheco Tunnel, } \\
\text { California, } \\
\text { metasandstone }\end{array}$ & $\begin{array}{l}20 . \\
41 . \\
60 \\
85 . \\
125 \\
180 \\
250\end{array}$ & $\begin{array}{l}24.0 \times 10^{-12} \\
2.9 \times 10^{-10} \\
18.6 \times 10^{-12} \\
5.90 \\
.44 \\
.16 \\
.21\end{array}$ & $\begin{array}{l}2.58 \times 10^{-4} \\
4.26 \\
4.14 \\
2.20 \\
.31 \\
.40 \\
.37\end{array}$ & $\begin{array}{l}229 . \\
291 . \\
218 . \\
126 . \\
60 \\
46 . \\
48\end{array}$ & $\begin{array}{r}8.7 \\
6.7 \\
5.2 \\
5.6 \\
18.8 \\
11.4 \\
12.6\end{array}$ \\
\hline $\begin{array}{l}\text { Monticello Damsite, } \\
\text { California, } \\
\text { sandstone and } \\
\text { shale }\end{array}$ & $\begin{array}{l}8 . \\
23 . \\
40 \\
66\end{array}$ & $\begin{array}{l}1.64 \times 10^{-10} \\
21.0 \times 10^{-12} \\
2.72 \\
.18\end{array}$ & $\begin{array}{l}5.74 \times 10^{-4} \\
1.08 \\
.59 \\
.14\end{array}$ & $\begin{array}{l}292 . \\
125 . \\
89 \\
41\end{array}$ & $\begin{array}{r}5.0 \\
11.4 \\
14.8 \\
29.4\end{array}$ \\
\hline $\begin{array}{l}\text { Virginia Ranch } \\
\text { Damsite, Calif. } \\
\text { abutment curtain } \\
\text { diabase }\end{array}$ & $\begin{array}{l}4 . \\
5 . \\
11 . \\
15 . \\
20 . \\
21 \\
25\end{array}$ & $\begin{array}{l}4.93 \times 10^{-12} \\
7.62 \\
2.99 \\
.56 \\
.40 \\
2.62 \\
1.69\end{array}$ & $\begin{array}{l}1.41 \times 10^{-4} \\
2.95 \\
1.46 \\
.31 \\
.26 \\
1.34 \\
.92\end{array}$ & $\begin{array}{r}121 . \\
157 . \\
126 . \\
106 . \\
76 . \\
141 . \\
79\end{array}$ & $\begin{array}{r}8.5 \\
5.2 \\
8.5 \\
33.6 \\
28.5 \\
10.3 \\
8.4\end{array}$ \\
\hline
\end{tabular}


Table 1. Summary of computed average properties of fractured rocks (continued).

\begin{tabular}{|c|c|c|c|c|c|}
\hline $\begin{array}{l}\text { Mid- } \\
\text { over }\end{array}$ & $\begin{array}{l}\text { depth below } \\
\text { burden }(f t)\end{array}$ & $\begin{array}{l}\text { permeability } \\
\quad\left(f t^{2}\right)\end{array}$ & porosity & $\begin{array}{l}\text { aperture } s \\
\text { (microns) }\end{array}$ & $\begin{array}{l}\text { spacing, cubic } \\
\text { system ( } f t)\end{array}$ \\
\hline $\begin{array}{l}\text { Virginia Ranch } \\
\text { Damsite, Calif. } \\
\text { channel curtain } \\
\text { diabase }\end{array}$ & $\begin{array}{l}5 . \\
11 \\
15 \\
18\end{array}$ & $\begin{array}{l}3.29 \times 10^{-12} \\
8.16 \times 10^{-14} \\
.79 \times 10^{-12} \\
.92\end{array}$ & $\begin{array}{l}.87 \times 10^{-4} \\
.032 \\
.19 \\
.93\end{array}$ & $\begin{array}{r}114 \\
37 \\
102 \\
77\end{array}$ & $\begin{array}{r}12.7 \\
113.2 \\
53.5 \\
8.1\end{array}$ \\
\hline $\begin{array}{l}\text { Auburn Damsite } \\
\text { No. } 2 \text {, California, } \\
\text { serpentine }\end{array}$ & $\begin{array}{r}13 \\
54 \\
125\end{array}$ & $\begin{array}{l}7.85 \times 10^{-10} \\
2.21 \times 10^{-12} \\
6.11 \times 10^{-14}\end{array}$ & $\begin{array}{l}2.46 \times 10^{-4} \\
.53 \\
.064\end{array}$ & $\begin{array}{l}424 \\
76 \\
28\end{array}$ & $\begin{array}{l}16.9 \\
14.1 \\
43.6\end{array}$ \\
\hline $\begin{array}{l}\text { Oakflat Damsite, } \\
\text { California, } \\
\text { basalt }\end{array}$ & 44. & $.47 \times 10^{-12}$ & $.82 \times 10^{-4}$ & 78 & 9.4 \\
\hline $\begin{array}{l}\text { Dark Canyon Dam- } \\
\text { site, Idaho, lime- } \\
\text { stone (undissolved) }\end{array}$ & $\begin{array}{l}14 . \\
60\end{array}$ & $\begin{array}{l}3.10 \times 10^{-10} \\
1.01 \times 10^{-12}\end{array}$ & $\begin{array}{l}1.13 \times 10^{-4} \\
1.31\end{array}$ & $\begin{array}{l}320 . \\
68 .\end{array}$ & $\begin{array}{r}27.8 \\
5.2\end{array}$ \\
\hline $\begin{array}{l}\text { Stampede Damsite, } \\
\text { California, } \\
\text { tuff-breccia, } \\
\text { tuff-siltstone }\end{array}$ & $\begin{array}{l}5 . \\
15 . \\
26 \\
36 \\
47 \\
66 \\
111 .\end{array}$ & $\begin{array}{l}5.46 \times 10^{-12} \\
7.49 \times 10^{-8} \\
2.04 \times 10^{-12} \\
1.15 \\
.88 \\
1.17 \\
.93\end{array}$ & $\begin{array}{l}2.03 \times 10^{-4} \\
\text { Inapp } 1 \text { icab } \\
1.28 \times 10^{-4} \\
1.17 \\
1.57 \\
1.09 \\
.78\end{array}$ & $\begin{array}{l}142 . \\
\text { le, no zeros } \\
109 . \\
92 . \\
75 . \\
90 . \\
83 .\end{array}$ & $\begin{array}{r}6.9 \\
\\
8.4 \\
7.7 \\
4.7 \\
8.1 \\
10.5\end{array}$ \\
\hline
\end{tabular}

